УДК 342.951

DOI https://doi.org/10.32837/pyuv.v2i3(28).365

Д.Г. Мулявка

кандидат юридичних наук, професор, завідувач кафедри оперативно-розшукової діяльності Університету державної ріскальної служби України

\title{
НАПРЯМИ ВДОСКОНАЛЕННЯ АДМІНІСТРАТИВНОГО ЗАКОНОДАВСТВА У СФЕРІ ПРАВОВОГО ЗАБЕЗПЕЧЕННЯ НЕДЕРЖАВНОЇ ОХОРОННОЇ ДІЯЛЬНОСТІ
}

Кардинальне оновлення національної правової систем вимагає перегляду існуючих в теорії адміністративного права підходів до сутності адміністративно-правового забезпечення недержавної охоронної діяльності в Україні. Складністю у цьому контексті є те, що вона поєднує у собі одночасно адміністративно-правові, господарсько-правові та цивільно-правові аспекти. Адміністративно-правовий аспект проблем удосконалення правового забезпечення недержавної охоронної діяльності вважається сьогодні найбільш важливим, оскільки ідеться про нове розуміння публічного інтересу у досліджуваній сфері. Вказане зумовлює актуальність та важливість дослідження проблем недержавної охоронної діяльності за допомогою засобів адміністративного права.

Проблеми, пов'язані із адміністративно-правовим забезпеченням охоронної діяльності, розглядали у своїх роботах О.М. Бандурка, М.В. Голуб, М.В. Завальний, С.В. Зюбаненко, О.М. Музичук, О.П. Угровецький та інші автори. Проте реформування правоохоронних органів і масштабні зміни національного законодавства вимагають оновлення підходів до адміністративно-правових аспектів здійснення охоронної діяльності.

Мета статті - визначення напрямів удосконалення адміністративного законодавства у сфері правового забезпечення недержавної охоронної діяльності.

Сьогодні в Україні здійснюється масштабна законотворча робота, спрямована на подолання тих суперечностей, які виникли за період існування нашої держави. Це амбітне і давно назріле завдання потребує продуманої реалізації, щоб поспіхом не ліквідувати ті правові механізми, які вже довели свою ефективність та відповідність конституційним принципам і міжнародним зобов'язанням нашої держави. Однак наявність проблем, які не вирішувалися протягом десятиліть, потребує рішучих дій, спрямованих на підвищення рівня захисту прав і законних інтересів учасників суспільних відносин. У сукупності сказане означає необхідність дотримуватися так званого серединного шляху, не роблячи поспішних кроків, але одночасно постійно рухаючись уперед, до побудови цивілізованої правоохоронної системи.

Слід сказати, що Закон України «Про охоронну діяльність» був прийнятий 22 березня 2012 року, а чинності він набрав 18 жовтня 2012 року. Цей правовий акт визначив особливості здійснення господарської діяльності у сфері надання послуг з охорони власності та громадян. У вказаному Законі містилися дефініції понять «охоронна діяльність», «об’єкт охорони», «суб’єкт охоронної діяльності», «охорона майна фізичної особи», «персонал охорони», «рахівець з організації заходів охорони» тощо.

Прийняття вказаного законодавчого акта слід розцінювати як позитивний крок на шляху до побудови цивілізованого ринку охоронних послуг. Водночас у вказаному Законі відзначалася велика кількість суперечностей та прогалин. Вони були пов' язані з тим, що система контролю за здійсненням господарської діяльності у сфері надання охоронних послуг у вказаному правовому акті була прописана фрагментарно. Це не давало можливості усвідомити сутність, принципи і засоби такого контролю. Однією з проблем, на якій наголошують вчені протягом багатьох років, є те, що організація, яка входить до сфери управління МВС України (поліція охорони Національної поліції України) надає охоронні послуги, а Міністерство внутрішніх справ України як центральний орган виконавчої влади, до сфери управління якого входить поліція охорони Національної поліції України, є суб'єктом контролю за здійсненням охоронної діяльності суб’єктами господарювання. МВС видає ліцензію на здійснення охоронних послуг.

Крім того, протягом кількох десятиліть поліція охорони (до створення Національної поліції України - Державна служба охорони при МВС України) залишається єдиною в Україні охоронною структурою, працівники якої на підставі закону мають повноваження на озброєну охорону, а також право застосовувати владні функції щодо правопорушників.

Слід сказати, що Державна служба охорони при МВС України, яка діяла на основі самофінансування, була створена 10 серпня 1993 року постановою Кабінету Міністрів України № 615 «Про заходи щодо вдосконалення охорони об'єктів державної та інших форм власності». Вказана Служба спочатку здійснювала переважно охорону державних особливо важливих об'єктів. Однак наприкінці 90 -х років минулого століття відбулася суттєва реорганізація структури і змісту діяльності Дер- 
жавної служби охорони при МВС України. Була активізована співпраця з органами господарювання в аспекті надання їм охоронних послуг. У цей час було створено спецпідрозділ міліції охорони «Титан», службу інкасації й інші структурні підрозділи, які надавали охоронні послуги. 14 лютого 2000 р. наказом МВС України № 96 було оголошено рішення колегії МВС України від 31 січня 2000 p. № $1 \kappa \mathrm{k} / 1$ «Про основні напрямки реформування Державної служби охорони при МВС України».

Згідно з Концепцією реформування Державної служби охорони при МВС України проводяться організаційні та практичні заходи зі звільнення працівників міліції охорони від виконання невластивих завдань, реорганізації воєнізованої та сторожової охорони Державної служби охорони у підрозділи цивільної охорони «Варта» та «Захист». Було створене Управління ліцензування та сертифікації технічних засобів охоронної та охоронно-пожежної сигналізації. Реалізуючи вимоги Концепції за визначеними напрямами і термінами, Головне управління і підпорядковані йому підрозділи на місцях здійснили низку організаційних і практичних заходів. Скоротилася кількість співробітників адміністративно-управлінського апарату, зникли непотрібні ланки управління, ліквідувалися збиткові підрозділи [1, с. 52-54; 2, с. 83-84].

Ринок охоронних послуг, які надавалися недержавними суб'єктами господарювання, мав свої тенденції розвитку, до яких слід віднести підвищення професіоналізації, технічної оснащеності, проте і періодичну тінізацію трудових відносин з персоналом, що була викликана переважно змінами податкової політики України. Так, після прийняття Закону України № 1233 від 12 грудня 2019 року, яким був скасований штраф у розмірі 30 мінімальних зарплат, що накладався на роботодавця за допуск до роботи без оформлення трудового договору, а замість нього встановилося адміністративне стягнення у вигляді попередження, можна прогнозувати, що тінізація трудових відносин на ринку охоронних послуг знову зросте. Втім, окрім непродуманої податкової політики, описані вище тенденції нерівної конкуренції на досліджуваному ринку роблять ситуацію ще більш важкою для недержавних охоронних підприємств.

3 огляду на сказане інтерес становить Звіт про результати дослідження впливу постанови Кабінету Міністрів України від 11 листопада 2015 року № 937 «Питання забезпечення охорони об'єктів державної та інших форм власності» на економічну конкуренцію на ринку охоронних послуг, схвалений Антимонопольним комітетом України 23.05.2016 року (протокол № 35). У ньому зазначається, що Комітетом у зв'язку з надходженням численних скарг суб'єктів господарювання - учасників ринку надання охоронних послуг - проведено дослідження впливу положень постанови Кабінету Міністрів України від 11.11.2015 р. № 937 «Питання забезпечення охорони об'єктів державної та інших форм власності» (далі - ПКМ № 937) на економічну конкуренцію у вказаній сфері. У ПКМ № 937 був затверджений перелік об'єктів державної та інших форм власності (далі - Перелік), охорона нерухомого майна яких здійснюється виключно органами поліції охорони. Крім того, ПКМ № 937 доручено міністерствам, іншим суб'єктам управління об'єктами державної власності вжити вичерпних заходів для переукладення з органами поліції охорони договорів про надання послуг з охорони, укладених $з$ Державною службою охорони при Міністерстві внутрішніх справ. Отже, метою дослідження $є$ визначення Комітетом стану конкурентного середовища на ринку охоронних послуг, оцінка впливу на нього ПКМ № 937 та внесення пропозицій щодо здійснення заходів, спрямованих на захист економічної конкуренції у разі, якщо дія положень ПКМ № 937 матиме на неї негативний вплив. У висновках вказаного документа визначено, що відсутність конкурентних умов у певних сегментах ринку, як правило, має негативні наслідки для споживачів послуг, які пов'язані зі зниженням якості послуг та зростанням їх вартості при незмінному попиті, який завдяки рішенням державних органів (ПКМ № 937) для органів поліції охорони залишається стабільним. При цьому відсутність конкурентної боротьби на окремому сегменті ринку між поліцією охорони та іншими учасниками ринку за споживача неодмінно призведе до порушення балансу на загальному ринку охоронних послуг, пов'язаного з розміром вартості послуг [3]. Хоча з моменту затвердження вказаної постанови минуло чотири роки, ситуація 3 конкуренцією на ринку охоронних послуг залишається проблемною і не сприяє справедливому суперництву між приватними охоронними підприємствами та поліцією охорони.

На підставі вказаного вище можна переконатися, що ринок охоронних послуг в Україні дестабілізований. Ця ситуація триває вже багато років. Окремо ï ускладнює відсутність в Україні вільного обігу зброї, безуспішні спроби запровадити який також тривають вже багато років. Способи вирішити ситуацію, що склалася, охоплюються двома такими основними напрямами: передаванням функцій ліцензування недержавної охоронної діяльності від МВС України іншому центральному органу виконавчої влади, а також позбавленням Національної поліції України і ї̈ структурного підрозділу - поліції охорони - права надавати охоронні послуги. На нашу думку, кожен з цих шляхів має свої вади, які не дозволяють визнати їх бездоганними. Проте окремої уваги заслуговує пропозиція щодо легалізації в Україні 
вільного обігу зброї. Ні система професійної підготовки правоохоронців, ні організація роботи 3 кадрами в Національній поліції України (як і в міліції України) жодним чином не може убезпечити від того, що табельна зброя може бути незаконно застосована (як у випадку з загибеллю п'ятирічного хлопчика у Переяславі-Хмельницькому Київської області у травні 2019 року). Отже, намагання держави залишити за собою монополію на обіг зброї постає недостатньо аргументованим. Однак вказане питання потребує подальших наукових досліджень з метою визначення умов, за яких легалізація вільного обігу зброї сприятиме підвищенню рівня законності та правопорядку, у тому числі й у сфері недержавної охоронної діяльності.

\section{Jimepamypa}

1. Мазепа М.М. Становлення та розвиток Державної служби охорони при МВС України на сучасному етапі. Право і безпека. 2011. № 2 (39) С. 51-55.

2. Шаповал В.I. Місце та призначення міліції охорони: доцільність ї̈ функціонування. Право України. 2004. № 3. C. $82-85$.

3. Звіт про результати дослідження впливу постанови Кабінету Міністрів України від 11.11.2015 р. № 937 «Питання забезпечення охорони об’єктів державної та інших форм власності» на економічну конкуренцію на ринку охоронних послуг, схвалений Антимонопольним комітетом України 23.05.2016 року, протокол № 35. URL: http://www.amc.gov.ua/amku/doccatalog/ document?id=125326\&schema=main (дата звернення: 11.11.2019).

4. Організаційно-правові засади професійної підготовки персоналу органів внутрішніх справ України : наук.-практ. посіб. / В.С. Венедиктов, М.І. Іншин, М.М. Клемпарський ; за заг. ред. проф. В.С. Венедиктова. Харків : Вид-во Нац. ун-ту внутр. справ, 2003. $212 \mathrm{c}$.

\section{Анотація}

Мулявка Д. Г. Напрями вдосконалення адміністративного законодавства у сфері правового забезпечення недержавної охоронної діяльності. - Стаття.

Стаття присвячена питанням удосконалення адміністративно-правового забезпечення недержавної правоохоронної діяльності. Кардинальне оновлення національної правової системи вимагає перегляду існуючих в теорії адміністративного права підходів до сутності адміністративно-правового регулювання недержавної охоронної діяльності в Україні. Дана проблема поєднує у собі одночасно адміністративно-правові, господарсько-правові та цивільно-правові аспекти. Автор обгрунтовує, що адміністративно-правовий аспект проблеми удосконалення правового забезпечення недержавної охоронної діяльності вважається сьогодні найбільш важливим, оскільки мова йде про нове розуміння публічного інтересу у досліджуваній сфері. Вказане зумовлюе актуальність та важливість дослідження проблем недержавної охоронної діяльності за допомогою засобів адміністративного права.

Автор доводить, що ситуація 3 конкуренцією на ринку охоронних послуг залишається проблемною і не сприяє справедливому суперництву між приватними охоронними підприємствами та поліцією охорони.
Ринок охоронних послуг в Україні дестабілізований. Ця ситуація триває вже протягом багатьох років. Ситуацію ускладнює відсутність в Україні вільного обігу зброї, безуспішні спроби запровадити який також тривають вже протягом багатьох років. Автор розглядає два основних способи вирішити ситуацію. Автор вважає, що неефективною буде передача функції ліцензування недержавної охоронної діяльності від МВС України іншому центральному органу виконавчої влади. Проте окремої уваги заслуговує пропозиція щодо легалізації в Україні вільного обігу зброї. Автор вважає, що намагання держави залишити за собою монополію на обіг зброї постає недостатньо аргументованим. Однак вказане питання потребує подальших наукових досліджень з метою визначення умов, за яких легалізація вільного обігу зброї сприятиме підвищенню рівня законності та правопорядку, у тому числі й у сфері недержавної охоронної діяльності.

Ключові слова: адміністративно-правове забезпечення, охоронна діяльність, охоронні послуги, ліцензування, обіг зброї, адміністративне законодавство.

\section{Summary}

Muliavka D. G. Directions for improving administrative legislation in the field of legal support of non-state security activities. - Article.

The article is devoted to improving the administrative and legal support of non-state law enforcement. The purpose of the article is to find the best ways to develop administrative legislation in the field of private security activities. A radical update of the national legal systems requires a review of the approaches to the essence of administrative regulation of non-state security activities in Ukraine that exist in the theory of administrative law. This issue combines at the same time administrative and legal, economic and civil aspects. The author substantiates that the administrative-legal aspect of the problems of improving the legal support of non-state security activities seems to be the most important today, since we are talking about a new understanding of public interest in the studied area. The above determines the relevance and importance of the study of urgent problems of private security activities by means of administrative law.

The author argues that the situation with competition in the security services market remains problematic and does not contribute to fair competition between private security companies and the security police. The market for security services in Ukraine is destabilized, and this situation has been going on for many years. The situation is complicated by the absence in Ukraine of free circulation of weapons, unsuccessful attempts to introduce which have also been going on for many years. The author considers two main ways to resolve the situation. The author believes that the transfer of the licensing function of private security activities from the Ministry of Internal Affairs of Ukraine to another central executive authority will be ineffective. At the same time, the proposal on the legalization of free circulation of weapons in Ukraine deserves special attention. The author believes that the state's attempts to leave behind its monopoly on arms trafficking are not sufficiently substantiated. However, this issue requires further scientific research in order to determine the conditions under which the legalization of free circulation of weapons will increase the level of law and order, including in the field of non-state security activities.

Key words: administrative and legal support, security activities, security services, licensing, arms trafficking, administrative legislation. 